JURNAL SEHAT MASADA VOLUME XV NOMOR $2 \quad$ Juli $2021 \quad$ ISSN : 1979-2344

\title{
HUBUNGAN PENGETAHUAN IBU HAMIL TENTANG KEBUTUHAN GIZI DENGAN POLA KONSUMSI PROTEIN SELAMA MASA KEHAMILAN DI PMB BIDAN M KABUPATEN CIANJUR
}

\author{
Oktarina Sri Iriani $^{1}$, Dyah Triwidiyantari ${ }^{2}$,Anisa Fitriasari $^{3}$ \\ ${ }^{1,2,)}$ Dosen Program Studi Diploma Tiga Kebidanan STIKes Dharma Husada \\ ${ }^{3}$ Mahasiswa Program Studi Diploma Tiga Kebidanan STIKes Dharma Husada \\ oktarina@Stikesdhb.ac.id \\ dyah@stikesdhb.ac.id \\ anfis.afs3@gmail.com
}

\begin{abstract}
Abstrak
Latar Belakang : Kekurangan pengetahuan ibu hamil terhadap gizi terutama jenis makronutrient seperti protein merupakan salah satu permasalahan yang akan mempengaruhi kondisi ibu selama kehamilan, banyak ibu hamil yang masih mengkonsumsi makanan dibawah Angka Kecukupan Gizi (AKG) selain itu kurangnya pengetahuan juga mengindikasi kan bahwa pola makan ibu rata - rata tidak sehat. Tujuan Penelitian : Penelitian ini bertujuan untuk mengetahui hubungan pengetahuan ibu hamil tentang kebutuhan gizi dengan pola konsumsi protein selama masa kehamilan. Metode : Metode yang digunakan adalah survey analitik, dengan analisis data menggunakan Univariat dan Bivariat menggunakan uji chi-square untuk melihat hubungan antara dua variabel dengan nilai $p<0,05$. Hasil penelitian : Hasil penelitian ini menunjukan dari 40 responden hampir setengahnya responden berpengetahuan cukup yaitu sebanyak 19 orang (47,5\%), lebih dari setengahnya responden mempunyai pola konsumsi baik yaitu sebanyak 23 orang (57,5\%). Dari hasil uji Chi-Square diperoleh nilai $\mathrm{p}$ sebesar 0,020 ( $\mathrm{p}$ value < 0,05). Kesimpulan : Penelitian ini menunjukan bahwa ada hubungan hubungan antara pengetahuan ibu hamil tentang kebutuhan gizi dengan pola konsumsi protein selama masa kehamilan.
\end{abstract}

Kata kunci : Pengetahuan ibu hamil, Kebutuhan Gizi, Pola Konsumsi

\begin{abstract}
Background: Lack of knowledge of pregnant women about nutrition, especially macronutrients such as protein is one of the problems that will affect the condition of the mother during pregnancy, many pregnant women still consume foods below the Nutritional Adequacy Rate (RDA). Research Objectives : This study aims to determine the relationship between knowledge of pregnant women about nutritional needs with protein consumption patterns during pregnancy. Methods : The method used is an analytical survey, with data analysis using Univariate and Bivariate usingtest chi-square to see the relationship between two variables with $p$ value $<0.05$. Research results : The results of this study showed that from 40 respondents, almost half of respondents had sufficient knowledge, namely 19 people $(47.5 \%)$, more than half of respondents had good consumption patterns, namely 23 people (57.5\%). From the results of thetest Chi-Square, a p value of 0.020 ( $p$ value < 0.05 ) was obtained. Conclusion : This study shows that there is a relationship between knowledge of pregnant women about nutritional needs with protein consumption patterns during pregnancy.
\end{abstract}

Keywords : Knowledge of pregnant women, Nutritional Needs, Consumption Patterns 
JURNAL SEHAT MASADA VOLUME XV

\section{PENDAhUluan}

Masa kehamilan memerlukan perhatian khusus karena merupakan periode penting 1.000 hari kehidupan ${ }^{1}$. Sepanjang tahap kehamilan, ibu hamil membutuhkan konsumsi makanan yang lebih dari semula, pola makan yang tepat juga asupan makronutrient yang seimbang ${ }^{1}$. Ibu hamil termasuk salah satu kelompok yang rawan gizi. Kebutuhan zat-zat gizi selama kehamilan tergantung dari status gizi, komposisi tubuh ibu, dan tingkat aktivitas fisik. Asupan gizi ibu hamil sangat berpengaruh terhadap pertumbuhan janin. Status gizi yang baik pada ibu hamil mencegah terjadinya kelainan pada bayi saat lahir, Berat Bayi Lahir Rendah (BBLR), infeksi, abortus dan Stunting ${ }^{2}$.

Salah satu faktor yang mempengaruhi gizi ibu hamil yaitu pengetahuan ibu hamil dan keluarga tentang zat gizi yang terkandung dalam makanan. Zat gizi yang bersangkutan adalah protein, besi, vitamin B6, vitamin B12, Asam folat, dan Vitamin E. Protein berperan dalam pengangkutan besi ke sumsum tulang untuk membentuk molekul haemoglobin sehingga ibu terhindar dari Anemia. Protein juga digunakan untuk proses pertumbuhan dan perkembangan janin, selain itu untuk pembentukan plasenta, cairan amnion, pertumbuhan jaringan uterus dan penambahan volume darah ${ }^{8}$.

Pada umumnya ibu hamil mengkonsumsi energi dibawah AKG (Angka Kecukupan Gizi) dan pola makan yang rata- rata tidak sehat. Berdasarkan hasil pemantauan Konsumsi Gizi (PKG) menunjukkan sebanyak 26,3\% ibu hamil yang memenuhi kecukupan energy dan 29,3\% ibu hamil yang memenuhi kecukupan protein dalam konsumsinya sehari-hari. Selama kehamilan diperlukan tambahan protein rata-rata 17 gram per hari atau disesuaikan dengan kebutuhan protein tiap trimester. Namun biasanya pada trimester terakhir kehamilan nafsu makan ibu hamil besar maka harus dibatasi untuk menghindari kegemukan, yang penting protein sudah mencapai $15 \%$ dari kebutuhan seluruh energi ${ }^{9}$.

Realita yang didapat di masyarakat bahwa kebanyakan ibu hamil usia muda masih kurang mendapatkan informasi dan arahan yang baik, mereka masih mengikuti dan menelan bulatbulat apa informasi yang disampaikan orang tua nya padahal tidak semua yang dikatakan itu benar karena terkadang ilmu atau informasi yang didapatkan belum diperbaharui atau sudah tertinggal, contohnya masih banyak orang tua yang melarang anaknya untuk mengkonsumsi daging, telur, cumi dsb dimana makanan tersebut merupakan sumber protein hewani yang baik untuk ibu hamil, namun tidak bisa dipungkiri jika Indonesia adalah bangsa yang memiliki keanekaragaman budaya yang terbentang dari Sabang sampai Merauke dengan latar belakang etnis, suku dan tata kehidupan sosial yang berbeda satu dengan yang lain. Hal ini telah memberikan suatu formulasi struktur sosial masyarakat yang turut mempengaruhi menu makanan maupun pola $\operatorname{makan}^{10}$.

Budaya memberi peranan dan nilai yang berbeda terhadap pangan dan makanan. Misalnya tabu makanan yang masih dijumpai 
JURNAL SEHAT MASADA VOLUME XV

dibeberapa daerah. Makanan tabu yang merupakan bagian dari budaya menganggap makanan makanan tertentu berbahaya karena alasan-alasan yang tidak logis. Hal ini mengindikasikan masih rendahnya pemahaman gizi masyarakat dan oleh sebab itu perlu berbagai upaya untuk memperbaikinya ${ }^{10}$.

Pengetahuan yang dimiliki seorang ibu akan mempengaruhi perilaku ibu termasuk dalam pengambilan keputusan. Namun di beberapa daerah masih dipengaruhi oleh budaya dan kepercayaan setempat juga seperti tidak boleh mengkonsumsi buah nanas, durian, tape pada saat hamil dikarenakan bisa berdampak pada lemahnya janin, tidak boleh mengkonsumsi ayam dikarenakan bisa menimbulkan gatal pada kulit, dan tidak boleh mengkonsumsi telur dikarenakan bayi yang ada di dalam kandungan bisa mengembang dari ukuran normal ${ }^{11}$. Pengetahuan tentang gizi yang perlu diketahui dan dipahami oleh ibu hamil meliputi pesan gizi seimbang, kebutuhan zat gizi, fungsi zat gizi, porsi makan ibu hamil, jenis makanan yang baik dikonsumsi ibu hamil serta bahan makanan yang harus dihindari agar tidak berdampak buruk pada kesehatan.

Rendahnya tingkat pengetahuan gizi pada saat kehamilan atau kelainan- kelainan yang kurang diperhatikan saat kehamilan yang pada akhirnya dapat menyebabkan resiko yang tidak diinginkan. Meski begitu Ibu dengan gizi yang baik, kemungkinan akan memenuhi kebutuhan gizi yang baik juga untuk bayinya. Sehingga ibu yang memiliki pengetahuan yang baik meskipun pada awal kehamilan mengalami beberapa masalah dan ketidaknyamanan maka
NOMOR 2 Juli 2021

ISSN : 1979-2344

ia akan tetap berusaha untuk memenuhi kebutuhan gizi dirinya dan juga bayinya ${ }^{11}$.

Berdasarkan masalah di atas maka peneliti tertarik untuk mengetahui apakah ada hubungan antara pengetahuan ibu hamil dengan pola konsumsi protein .

\section{METODOLOGI PENELITIAN}

Jenis penelitian bersifat survey analitik dengan desain cross sectional. Penelitian dilakukan di Praktek Mandiri Bidan M yang berada di Kabupaten Cianjur, teknik pengambilan sampel menggunakan total sampling. Sampel yang digunakan berjumlah 40 orang ibu hamil. Data yang dikumpulkan meliputi pengetahuan ibu tentang kebutuhan gizi dan pola konsumsi protein ibu selama hamil

Data pengetahuan ibu diperoleh melalui wawancara menggunakan kuesioner, meliputi pengetahuan ibu secara umum tentang gizi dan khusus tentang zat gizi protein. Pengetahuan ibu dikatakan Baik, jika jawaban benar 76100\%, Cukup, jika jawaban benar 56-75\% dan Kurang, jika jawaban benar $<55 \%$.

Pola konsumsi protein diperoleh dengan wawancara langsung menggunakan form SemiQuantitative Food Frequency Questionnaires dengan skala ukur kurang, jika asupan protein $<80 \%$ dari total kebutuhan protein, dan baik jika asupan protein $>80 \%$ dari total kebutuhan protein

\section{HASIL DAN PEMBAHASAN}

\section{A. Hasil}

Sampel penelitian ini adalah 40 orang ibu hamil yang melakukan pemeriksaan hasil yang 
JURNAL SEHAT MASADA VOLUME XV

didapat mengenai hubungan pengetahuan ibu tentang kebutuhan gizi dengan pola konsumsi protein selama masa kehamilan dapat dilihat pada tabel. Berdasarkan tabel 4.1 didapatkan hasil bahwa pengetahuan ibu hamil tentang kebutuhan gizi selama hamil di Bidan $\mathrm{M}$ Kabupaten Cianjur hampir setengahnya responden berpengetahuan cukup yaitu sebanyak 19 orang $(47,5 \%)$.

Tabel 1 Distribusi Frekuensi Pengetahuan Ibu Hamil tentang Kebutuhan Gizi Selama Hamil di Bidan M Kabupaten Cianjur

\begin{tabular}{ccc}
\hline Pengetahuan & F & \% \\
\hline Baik & 12 & 30,0 \\
Cukup & 19 & 47,5 \\
Kurang & 9 & 22,5 \\
\hline Total & 40 & 100,0 \\
\hline
\end{tabular}

NOMOR 2 Juli 2021

ISSN : 1979-2344

Pada tabel 1 didapatkan hasil bahwa pengetahuan ibu hamil tentang kebutuhan gizi selama hamil, paling banyak kategori cukup $(47,5 \%)$

Tabel 2 Distribusi Frekuensi Pola Konsumsi Asupan Protein Ibu Hamil Selama Kehamilan di Bidan M Kabupaten Cianjur

\begin{tabular}{ccc}
\hline Pola Konsumsi & F & \% \\
\hline Baik & 23 & 57,5 \\
Kurang & 17 & 42,5 \\
\hline Total & 40 & 100,0 \\
\hline
\end{tabular}

Pada tabel 2 didapatkan hasil bahwa pola konsumsi asupan protein ibu hamil selama kehamilan di Bidan M Kabupaten Cianjur lebih dari setengahnya responden mempunyai pola konsumsi baik yaitu sebanyak 23 orang $(57,5 \%)$

Tabel 3 Hubungan Pengetahuan Ibu Hamil terhadap Kebutuhan Gizi dengan Pola Konsumsi Protein Selama Kehamilan di Bidan M Kabupaten Cianjur

\begin{tabular}{|c|c|c|c|c|c|c|c|}
\hline \multirow{3}{*}{ Pengetahuan } & \multicolumn{4}{|c|}{ Pola Konsumsi Protein } & \multirow{2}{*}{\multicolumn{2}{|c|}{ Total }} & \multirow{3}{*}{ P Value } \\
\hline & \multicolumn{2}{|c|}{ Baik } & \multicolumn{2}{|c|}{ Kurang } & & & \\
\hline & $\mathrm{n}$ & $\%$ & $\mathrm{n}$ & $\%$ & $\mathrm{n}$ & $\%$ & \\
\hline Baik & 10 & 83.3 & 2 & 16,7 & 12 & 100 & \\
\hline Cukup & 11 & 57.9 & 8 & 42,1 & 19 & 100 & 0,020 \\
\hline Kurang & 2 & 22,2 & 7 & 77,8 & 9 & 100 & \\
\hline Jumlah & 23 & $\mathbf{5 7 , 5}$ & 17 & 42,5 & 40 & 100 & \\
\hline
\end{tabular}

Pada tabel 3 menunjukkan bahwa responden dengan kategori tingkat pengetahuan cukup lebih dari setengahnya yaitu 11 orang $(57,9 \%)$ memiliki pola konsumsi protein baik dan yang memiliki pola konsumsi protein kurang sebanyak 8 orang $(42,1 \%)$, tingkat pengetahuan baik hampir keseluruhan yaitu 10 orang $(83,3)$ memiliki pola konsumsi protein baik dan yang memiliki pola konsumsi protein kurang sebanyak 2 orang $(16,7 \%)$, tingkat pengetahuan kurang kurang dari setengahnya yaitu 2 orang $(22,2)$ memiliki pola konsumsi protein baik dan yang memiliki pola konsumsi protein kurang sebanyak 7 orang $(77,8 \%)$,

Hasil analisis data dengan menggunakan uji Chi-Square didapatkan nilai p value sebesar $0,020$ ( $\mathrm{p}$ value < 0,05$)$ sehingga dapat diketahui bahwa terdapat hubungan yang signifikan antara pengetahuan ibu hamil 
JURNAL SEHAT MASADA VOLUME XV

terhadap kebutuhan gizi dengan pola konsumsi protein selama kehamilan di Bidan $M$ Kabupaten Cianjur. Berdasarkan hasil yang didapat maka dapat disimpulkan bahwa hipotesis Ho ditolak dan Ha diterima.

\section{B. Pembahasan}

\section{Pengetahuan ibu hamil tentang kebutuhan gizi selama hamil di Bidan M Kabupaten Cianjur}

Berdasarkan hasil penelitian menyebutkan bahwa pengetahuan ibu hamil tentang kebutuhan gizi selama hamil di Bidan $M$ Kabupaten Cianjur hampir setengahnya responden berpengetahuan cukup yaitu sebanyak 19 orang $(47,5 \%)$.

selama hamil berpengaruh terhadap konsumsi makanan yang dibutuhkan selama kehamilan sehingga dengan begitu menjadikan responden tidak mengetahui makanan apa saja yang dibutuhkan untuk memenuhi nutrisi selama kehamilan khususnya protein mana yang bagus untuk perkembangan janinnya dan metabolisme tubuhnya. Menurut Surasih, kurangnya pengetahuan ibu hamil tentang kebutuhan gizi selama hamil dapat menyebabkan kurangnya asupan makanan yang bergizi yang berpengaruh juga terhadap perkembangan janin akibatnya saat janin lahir mengalami BBLR, infeksi atau perkembangan otak tidak sempurna, ketika masa bertumbuh pun akan terhambat, karena pada dasarnya pengetahuan tentang kebutuhan gizi selama hamil sangat berguna bagi sang ibu sendiri, karena itu kebutuhan protein dan zat gizi lainnya sangat meningkat selama kehamilan. Ibu dengan pengetahuan yang baik mengerti
NOMOR 2 Juli 2021

ISSN : 1979-2344

dengan benar betapa diperlukannya peningkatan pola konsumsi protein yang cukup untuk membuat janin tumbuh dengan sempurna ${ }^{25}$.

\section{Pola konsumsi asupan protein ibu hamil selama kehamilan di Bidan M Kabupaten Cianjur}

Berdasarkan hasil penelitian menyebutkan bahwa pola konsumsi asupan protein ibu hamil selama kehamilan di Bidan M Kabupaten Cianjur lebih dari setengahnya responden mempunyai pola konsumsi baik yaitu sebanyak 23 orang $(57,5 \%)$.

Pada penelitian ini ditemui bahwa jenis makanan sumber protein yang banyak dikonsumsi oleh ibu hamil adalah jenis protein hewani seperti daging ayam, daging sapi, daging kambing, telur ayam, telur bebek, telur puyuh, ikan tawar, dan protein nabati seperti tahu, tempe, kacang tanah, kacang merah, kacang hijau, oncom.

Pada ibu hamil protein berfungsi untuk pertumbuhan dan perkembangan janin, plasenta uterus, payudara, serta peningkatan volume darah ibu. Penambahan protein dibutuhkan pada masa kehamilan untuk menutupi perkiraan 925 gr protein yang dideposit dalam janin, plasenta dan jaringan maternal. Penambahan protein tiap hari bisa mengacu pada anjuran dimana lebar atau porsinya itu selebar telapak tangan, penggunaan protein adalah $=67-70 \%$, rata-rata wanita hamil akan membutuhkan pertambahan 8,5 gr protein/hari. Sebagian besar protein dianjurkan berasal dari sumber hewani, misalnya daging susu, telur, keju, produk ayam 
dan ikan, karena makanan-makanan ini mengandung kombinasi asam amino yang optimal. Susu dan produk turunan susu telah lama dianggap sebagai sumber nutrisi, terutama protein dan kalsium yang ideal bagi wanita hamil ${ }^{18}$.

Beberapa ibu hamil dalam penelitian ini mengalami gizi kurang penyebabnya karena masih mengikuti budaya dari orang tua nya yang melarang untuk mengkonsumsi salah satu zat gizi seperti protein, selain itu juga ibu membatasi jenis protein yang dikonsumsi nya karena mempunyai alergi terhadap beberapa makanan, sehingga penyerapan asupan protein tidak maksimal. Gizi kurang pada ibu hamil dapat menyebabkan resiko dan komplikasi pada ibu diantara lain : anemia, perdarahan, berat badan ibu tidak bertambah secara normal,Kekurangan Energi Kronis (KEK) dan terkena penyakit infeksi sedangkan gizi berlebih pada ibu hamil akan menyebabkan obesitas sangat beresiko untuk mengalami penyakit-penyakit seperti hipertensi dalam kehamilan, diabetes gestasional, gangguan pernafasan dan tromboemboli ${ }^{15}$.

\section{Hubungan pengetahuan ibu hamil terhadap kebutuhan gizi dengan pola konsumsi protein selama kehamilan di Bidan $M$ Kabupaten Cianjur}

Berdasarkan hasil penelitian menyebutkan bahwa responden dengan kategori tingkat pengetahuan cukup lebih dari setengahnya yaitu 11 orang $(57,9 \%)$ memiliki pola konsumsi protein baik dan yang memiliki pola konsumsi protein kurang sebanyak 8 orang $(42,1 \%)$, tingkat pengetahuan baik hampir keseluruhan yaitu 10 orang $(83,3)$ memiliki pola konsumsi protein baik dan yang memiliki pola konsumsi protein kurang sebanyak 2 orang $(16,7 \%)$, tingkat pengetahuan kurang kurang dari setengahnya yaitu 2 orang $(22,2)$ memiliki pola konsumsi protein baik dan yang memiliki pola konsumsi protein kurang sebanyak 7 orang $(77,8 \%)$,

Hasil analisis data dengan menggunakan uji Chi-Square didapatkan nilai p value sebesar $0,020(\mathrm{p}<0,05)$ sehingga dapat diketahui bahwa terdapat hubungan yang signifikan antara pengetahuan ibu hamil terhadap kebutuhan gizi dengan pola konsumsi protein selama kehamilan di Bidan M Kabupaten Cianjur

Pengetahuan ibu tentang kebutuhan gizi selama hamil dan pola konsumsi protein sangat berpengaruh terhadap janin dan ibu selama kehamilannya karena menurunnya konsentrasi protein atau kekurangan asupan protein dapat mengakibatkan penurunan kadar albumin serum dimana nilai kadar Haemoglobin juga akan turun.

Penelitian ini sejalan dengan penelitian yang dilakukan oleh Adhiyati ${ }^{26}$, (2013) yang menyatakan bahwa ada hubungan antara pengetahuan dengan status gizi ibu hamil di Kecamatan Terbanggi Besar Kabupaten Lampung Tengah Propinsi Lampung dengan tingkat hubungan (nilai Signifikan) $p=0,020$ $(\mathrm{p}<0.05)$. Semakin baik pengetahuan ibu maka ibu akan memberikan nutrisi terbaik untuk janinnya dan pemilihan jenis makanannya pun akan beragam. 
Menurut Ernawati (2012), mengatakan bahwa pengetahuan merupakan salah satu faktor yang mempengaruhi status gizi ibu hamil, kurangnya pengetahuan dan salah persepsi tentang kebutuhan pangan dan nilai pangan juga dapat mempengaruhi status gizi seseorang. Selain itu lebih muda umur ibu hamil maka energi yang dibutuhkan semakin banyak, semakin banyak aktivitas yang dilakukan maka semakin banyak pula asupan gizi yang diperlukan. Berat badan lebih atau kurang dari berat badan rata-rata untuk umur tertentu juga merupakan faktor yang menentukan jumlah zat makanan yang harus dicukupi selama hamil ${ }^{27}$.

Yuliantini (2013) yang menyatakan Konsumsi energi dan protein yang kurang selama jangka waktu tertentu akan menyebabkan status gizi tidak normal atau mengalami KEK, sehingga untuk menjamin kesehatan ibu hamil, maka perlu mengkonsumsi makanan yang mengandung protein dan vitamin selama kehamilan ${ }^{4}$.

Hasil penelitian ini berkaitan juga dengan Rahmaniar (2013), menyatakan bahwa terdapat hubungan pola makan dengan status gizi ibu hamil di Puskesmas Tampa Padang, Kabupaten Mamuju, Sulawesi Barat, menggunakan korelasi Kendal Tau didapatkan hasil z hitung $0,596>\mathrm{z}$ tabel 0,281 dengan tingkat signifikasi $95 \%$ ini menunjukan bahwa terdapat hubungan yang cukup kuat antara pola makan dengan status gizi pada ibu hamil ${ }^{28}$.

Pola makan ibu hamil mempunyai hubungan dengan status gizinya, hal ini dikarenakan pola makan ibu hamil dapat memberikan asupan untuk tetap menjaga berat badan selama mengandung, makanan yang dikonsumsi harus banyak mengadung protein dan vitamin tujuannya agar terhindar dari kekurangan energi kronik yang dapat mempengaruhi status gizinya. Faktor pengetahuan dan pengalaman serta pola makan ibu hamil sangat penting untuk mencukupi kebutuhan protein ibu hamil dan janinnya. Adanya ibu hamil dengan tingkat pola makan yang baik tetapi masih menderita status gizi kurang, disebabkan karena protein yang dikonsumsi ibu hamil mempunyai kualitas yang kurang baik.

\section{SIMPULAN}

Dari hasil penelitian ini ditemukan bahwa ada hubungan antara pengetahuan ibu hamil tentang kebutuhan gizi dengan pola konsumsi protein selama masa kehamilan di PMB Bidan M Kabupaten Cianjur.

\section{DAFTAR PUSTAKA}

1. Sudargo, toto, dkk. 1000 Hari Pertama Kehidupan. Yogyakarta : Gadjah Mada University Press.2018.

2. Almatsier, Sunita. Prinsip Dasar Ilmu Gizi. Jakarta: PT. Gramedia Pustaka Utama .2016.

3. Ambarwati. Gizi \& Kesehatan Reproduksi, Cakrawala Ilmu. Yogyakarta.2018.

4. Yuliantini. Hubungan Antara Konsumsi Energi dan Protein dengan Status Gizi Pada Ibu Hamil di Wilayah Kerja Puskesmas I Sukoharjo Kabupaten 
Sukoharjo. Jurnal Kesehatan Masyarakat Indonesia. 2013.

5. World Health organization. Maternal mortality Evidance brief. Matern Mortal . 2017;(1):1-4

6. Kementrian Kesehatan RI. Profil Kesehatan Indonesia 2019. Kementrian Kesehat RI. 2019;8(9):1-58.

7. Riskesdas, T. Laporan Provinsi Jawa Barat Riskesdas 2018. (Lembaga Penerbit Badan Penelitian dan Pengembangan Kesehatan (LPB), 2018).

8. Muliarini. Pola Makan \& Gaya Hidup Sehat Selama Kehamilan. Cetakan Kedua. Yogyakarta.2015.

9. Miyata.I.M.S, Proverawati.A. Nutrisi Janin dan Ibu hamil, Cetakan Kedua. Yogyakarta.2015.

10. Afiyah Sri Harnany. Pengaruh Tabu Makanan tingkat Kecukupan gizi, konsumsi zat Besi, dan teh terhadap kadar Hemoglobin pada ibu hamil di Kota Pekalongan. Universitas Diponegoro, Semarang. 2014

11. Muliarini. Pola Makan \& Gaya Hidup Sehat Selama Kehamilan. Cetakan Kedua. Yogyakarta. 2015.

12. Kurniawati, Heny.Tingkat Pengetahuan Ibu Hamil Primigravida Tentang Kebutuhan Gizi Selama Kehamilan di Puskesmas Jetis II Bantul. (Skripsi). Kebidanan Sekolah Tinggi Ilmu Kesehatan Jendral Achmad Yani Yogyakarta.2016.
13. Kurnia Dewi, dkk.Ilmu Gizi untuk Praktisi Kesehatan. Cetakan Kedua. Yogyakarta: Graha Ilmu. 2018.

14. Hardinsyah, \& Supariasa, I. D. Ilmu Gizi Teori dan Aplikasi. Jakarta: Penerbit Buku Kedokteran. 2016.

15. Notoatmodjo,Soekidjo. Pendidikan dan Perilaku Kesehatan. 2019.

16. Damayanti Didit, Pritasari , Tri Nugraheni. Gizi Dalam Daur Kehidupan. 2019. 292 hal.

17. Holil M, Wiyono Sugeng, Priyo Titus. Penilaian Status Gizi. 2017. 315 hal

18. La Banudi. Gizi Kesehatan Reproduksi : Buku Saku Bidan. Jakarta. EGC. 2012.

19. Almatsier Sunita. Prinsip Dasar Ilmu Gizi edisi ke 9. Jakarta. Gramedia Pustaka Utama. 2015.

20. Habibah Arsinah, Nyoman Dewa et al. Praktis Gizi Ibu Hamil. Edisi 1. Malang. Media Nusa Creative. 2018. Viii+74.

21. Sirajuddin, Surmita, Astuti Trina. Survey Konsumsi Pangan. 2018. 381 hal.

22. Masturoh Imas, Anggita Nauri. Bahan Ajar Rekam Medis dan Informasi Kesehatan : Metodologi Penelitian. 2018. 307 hal.

23. Puji Esse, Satriani Sri et al. Hubungan Pengetahuan Ibu Dan Pola Konsumsi Dengan Kejadian Anemia Gizi Pada Ibu Hamil Di Puskesmas Kassi - Kassi. Jurnal Media Gizi Pangan. 2010.

24. Notoatmodjo, Soekidjo. Promosi Kesehatan dan Perilaku Kesehatan. Jakarta. Rineka Cipta. 2014. h. 131-207 
JURNAL SEHAT MASADA VOLUME XV

25. Surasih, H. Faktor-Faktor yang Berhubungan dengan Keadaan Kurang Energi Kronis (KEK) pada Ibu Hamil. 2015.

26. Adhiyati. Hubungan Pengetahuan dan Asupan Gizi Terhadap Kejadian KEK Pada Ibu Hamil di Kecamatan Terbanggi Besar Kabupaten Lampung Tengah Propinsi Lampung. Tesis, Universitas Gajah Mada.2013.

27. Ernawati. Hubungan Pengetahuan Ibu Hami Tentang Anemia Defisiensi Besi Dengan Kepatuhan Mengkonsumsi Tablet Besi di Puskesmas Karangdowo, Klaten.
NOMOR 2 Juli 2021

ISSN : 1979-2344

Jurnal Kesehatan, ISSN 1979-7621, Vol5 (2) : 110-118.2012.

28. Rahmaniar. Faktor-Faktor yang Berhubungan dengan Kekurangan Energi Kronis Pada Ibu Hamil di Tampa Padang, Kabupaten Mamuju, Sulawesi Barat. Makassar. Pascasarjana Universitas Hasanuddin. 2013. 